Received 28.04.2017 Reviewed 21.11.2017 Accepted 21.11.2017

A - study design

B - data collection

C - statistical analysis

D - data interpretation

$\mathbf{E}$ - manuscript preparation

F - literature search

\section{Changes of species composition of the Poa pratensis-Festuca rubra plant communities in drainage peatland}

Danuta URBAN ${ }^{\text {ACDE }}$, Antoni GRZYWNA ABDEF $ه$

\footnotetext{
1) University of Life Sciences in Lublin, Faculty of Production Engineering, Department of Soil Sciences and Environmental Engineering, ul. Leszczyńskiego 7, 20-069 Lublin, Poland; e-mail: danuta.urban@up.lublin.pl

2) University of Life Sciences in Lublin, Faculty of Production Engineering, Department of Environmental Engineering and Geodesy, ul. Leszczyńskiego 7, 20-069 Lublin, Poland; e-mail: antoni.grzywna@up.lublin.pl
}

For citation: Urban D., Grzywna A. 2017. Changes of species composition of the Poa pratensis-Festuca rubra plant communities in drainage peatland. Journal of Water and Land Development. No. 35 p. 243-248. DOI: 10.1515/jwld-2017-0090.

\begin{abstract}
The objective of this study was to examine the vegetation cover and describe the floristic diversity of selected plant communities of extensive and abandoned grasslands within the Forest of Parczew PLB060006 a Natura 2000 protected area. Floristic surveys were conducted in the meadows in years 2001 and 2013 under the conditions of natural succession of the communities Poa pratensis-Festuca rubra. The area is situated in the northern part of the Lublin Voivodeship, in the physiographic mesoregion the Łęczna-Włodawa Lakeland. Those communities were characterized by average species richness and floristic diversity index values. The cover index decreased considerably in the case of 8 species, and increased for 12 species. A large increase in the cover index of Holcus lanatus, Deschampsia caespitosa, Galium mollugo, Anthriscus sylvestris and Polemonium caeruleae is particularly noteworthy. In 2001, 39 species of plants were recorded in all relevés, compared to 41 species recorded in 2013. Over 12 years, 11 species disappeared, but 13 new ones emerged. For the time being, the average species richness $\mathrm{N}$ increased from 12 to 16 per relevé. The biodiversity index $H^{\prime}$ increased from 2.8 to 3.6 .
\end{abstract}

Key words: diversity index, relevés, river valley, species richness

\section{INTRODUCTION}

The meadows are special for their set of plant species belonging to the prevailing specific abiotic conditions such as high ground water levels and soils. Nature management in the meadows generally is focused on the removal of biomass and accompanying nutrients by yearly hay making. Much knowledge is available on the processes that govern the conservation and restoration of wetlands. However most of this information comprises the ecohydrological and landscape ecological features that concern the plant compartment of this system [WOODCOCK et al. 2012].

Early successional theories that plants characteristic of early-seral environments are gradually replaced by more competitive later-seral species. However, re- cent studies by applied ecologists suggest that nonequilibrium dynamics prevail [WALLINGTON et al. 2005], especially at smaller spatial scales where initial colonisers have been shown to have a strong influence on future community composition [FUKAMI et al. 2005].

The field of restoration ecology can not only improve degraded lands but also test theories of ecosystem succession by examining community responses to direct manipulations of ecosystem function and structure. By manipulating ecosystem processes, such as propagate dispersal [FOSTER, TILMAN 2003], practitioners can alter the rate and trajectory of ecosystem recovery while improving our understanding of the constraints to ecosystem development. On sites of low species richness or where seed bank and propagate sources are limited, seed additions can be a useful 
method to accelerate ecosystem succession [HOELZLE et al. 2012].

Two kinds of observations of disturbed plant communities have inspired much of the research on succession. The first is that they progress through a set of different community states, with certain common characteristic sin a wide variety of ecosystems. The second is that they tend to develop back to a state similar to the original one, from different starting points. Despite the current aversion to the classical approach, the fact remains that many terrestrial communities do tend to return to pre disturbance states in predictable way [LEPS et al. 2000].

Species diversity is the critical property of plant communities and is of considerable significance in the study of succession, since variations in diversity are presumably correlated with the stability of various biotic components of ecosystems. The diversity of plant species present at certain stages of succession may affect the course of succession [VAN DER PUTTEN et al. 2000]. Biodiversity has become an important measure for the evaluation of ecosystems, although the role of species diversity in ecosystem functioning is disputed [ZHANG et al. 2005].

The aim of the study was to analyse changes in the species composition of the Poa pratensis-Festuca rubra communities. Phytosociological relevés were made in 2001 and repeated at the same sites in 2013. The number of species and biodiversity index was calculated for each relevé, and the specific range of cover and cover index were determined for each of the species.

\section{MATERIALS AND METHODS}

The objective of this study was to examine the vegetation cover and describe the floristic diversity of selected plant communities of extensive grasslands in the Natura 2000 protected area of The Forest of Parczew PLB060006. The grassland, drained in the years 1930-1932, was 458 ha with a total catchment area amounting to $33.1 \mathrm{~km}^{2}$. The average decline is $1.5 \%$ for the analysed basin. The tests were performed in alder peatland and have been ecologically used since 1992. Floristic surveys were conducted in the meadows in 2001 and repeated in 2013 in the conditions of the natural succession of communities Poa pratensisFestuca rubra. The area is situated in the northern part of the Lublin Voivodeship, in the physiographic mesoregion the Łęczna-Włodawa Lakeland. There, communities of the Molinio-Arrhenatheretea class are most rich in species. They account for $75 \%$ of all plant communities in grasslands, in the middle reaches of the Ochoża River valley. The protection is covered by species of the Arrhenatherion and Molinion alliances. There are also small patches that cover many species and deserve protection because of their significant landscapes attribute. The Ochoża is an anthropogenic river, constantly changing its channel and deeply incised into the valley [URBAN, GRZYWNA 2003]. The lowering of the water level caused by drainage led to rapid changes in the habitat properties and in the natural arrangement of plant communities. Economically valuable mesophytes appeared in all sites with hygrophilous plants.

In the study area, 13 phytosociological relevés were made at the same sites within homogeneous vegetation patches, with an area of $25 \mathrm{~m}^{2}$ (on permanent, stabilized plots). Species composition of the sward was assessed using the Braun-Blanquet method. The constancy, cover index and the range of cover were determined for all species. The nomenclature of species was according to MIREK et al. [2002], with the taxonomy and nomenclature of communities according to MATUSZKIEWICZ [2007]. Species richness $N$ (number of species in a relevé) and the ShannonWiener diversity index $H^{\prime}$ was used to assess the species diversity of plant communities.

\section{RESULTS}

Typical meadow communities covered areas of different size in the middle reaches of the Ochoża River valley $-51^{\circ} 33^{\prime} 50^{\prime \prime} \mathrm{N}, 22^{\circ} 52^{\prime} 40^{\prime}$ E. They were representative of the Poa pratensis-Festuca rubra community (Tab. 1).

Analysis of the data presented indicates that Poa pratensis, Festuca rubra, and Urtica dioica occurred in all relevé in 2001 and 2013. Simultaneously, these species had the highest cover index (Poa pratensis $D=7250$ in 2001 and $D=2175$ in 2013, Urtica dioi$c a-D=1828$ in 2001 and $D=2078$ in 2013). In 2013, besides the species mentioned above, Rumex acetosa, Galium mollugo, Veronica chamaedrys, and Cardaminopsis arenosa were present in the analysed localities. Analysis of the results shown in Table 1 reveals that the constancy index of 15 species increased in 2013, compared with that in 2001, while that of other species did not change. There has been a change in the cover index. The cover index of 8 species decreased considerably, while 13 species increased. The cover of Poa pratensis dropped markedly (the range of cover decreased from 4 to 3 ), whereas that of Deschampsia caespitosa increased (the range of cover increased from 1 to 3). A large increase in the cover index of Holcus lanatus, Deschampsia caespitosa, Galium mollugo, Anthriscus sylvestris and Polemonium caeruleae (a protected species in Poland) is particularly noteworthy. In 2001, 39 species of plants were recorded in all relevés, compared to 41 species recorded in 2013. Over 12 years, 11 species disappeared, but 13 new ones emerged.

These communities were characterized by means of species richness and floristic diversity index values. The greatest diversity $\left(H^{\prime}=2.8\right.$ in $2001, H^{\prime}=3.6$ in 2013) was shown by vegetation (Tab. 2) that formed small patches in unused meadows meadows (no fertilization). 39 plant species were found to occur in the sward of this community (mean, 12 species per relevé in 2001 and 16 in 2013) representing mainly the Molinio-Arrhenatheretea class, with a clear predominance of Poa pratensis and Festuca rubra. 
Table 1. Characteristics of the Poa pratensis-Festuca rubra plant community

\begin{tabular}{|c|c|c|c|c|c|c|}
\hline \multirow{2}{*}{$\begin{array}{c}\text { Species characteristic of relevés } \\
\text { Year }\end{array}$} & \multicolumn{2}{|c|}{ Range of cover } & \multicolumn{2}{|c|}{ Cover index } & \multicolumn{2}{|c|}{ Constancy } \\
\hline & 2001 & 2013 & 2001 & 2013 & 2001 & 2013 \\
\hline \multicolumn{7}{|l|}{ Cl. Molinio-Arrhenatheretea $\mathbf{R}$. Tx. } \\
\hline Poa pratensis L. s. str. & $3-5$ & $2-3$ & 7250 & 3150 & $\mathrm{~V}$ & $\mathrm{~V}$ \\
\hline Festuca rubra L. s. str. & $2-3$ & $2-3$ & 2575 & 2175 & $\mathrm{~V}$ & $\mathrm{~V}$ \\
\hline Rumex acetosa $\mathrm{L}$. & + & +-2 & 176 & 406 & $\mathrm{I}$ & $\mathrm{V}$ \\
\hline Cerastium holosteoides Fr. emend. Hyl. & + & + & 5 & 7 & III & IV \\
\hline Alopecurus pratensis L. & 2 & +-3 & 700 & 1075 & III & III \\
\hline Holcus lanatus L. & 2 & $2-3$ & 50 & 1075 & $\mathrm{I}$ & III \\
\hline Phleum pratense L. & + & - & 1 & - & $\mathrm{I}$ & - \\
\hline \multicolumn{7}{|l|}{ All. Polygonion avicularis Br.-Bl. } \\
\hline Lolium perenne L. & + & + & 1 & 1 & I & I \\
\hline \multicolumn{7}{|l|}{ O. Agropyro-Rumicion crispi Nordh. } \\
\hline Ranunculus repens L. & +-2 & +-2 & 103 & 56 & III & IV \\
\hline Potentilla anserina $\mathrm{L}$. & + & + & 178 & 3 & II & III \\
\hline Agrostsis stolonifera L. & + & + & 175 & 12 & $\mathrm{I}$ & $\mathrm{I}$ \\
\hline Carex hirta $\mathrm{L}$. & + & + & 1 & 1 & $\mathrm{I}$ & $\mathrm{I}$ \\
\hline \multicolumn{7}{|l|}{ O. Molinietalia W. Koch } \\
\hline Deschampsia caespitosa P. Beauv. & +-2 & $2-3$ & 351 & 1677 & II & IV \\
\hline Equisetum palustre L. & - & + & - & 4 & - & II \\
\hline Angelica sylvestris L. & + & + & 1 & 1 & I & $\mathrm{I}$ \\
\hline \multicolumn{7}{|l|}{ All. Filipendulion ulmariae Segal } \\
\hline Lythrum salicaria $\mathrm{L}$. & + & +-1 & 1 & 50 & I & II \\
\hline Filipendula ulmaria Maxim. & + & + & 1 & 1 & $\mathrm{I}$ & $\mathrm{I}$ \\
\hline Lysimachia vulgaris L. & 1 & - & 50 & - & $\mathrm{I}$ & - \\
\hline Valeriana officinalis L. & - & + & - & 1 & - & $\mathrm{I}$ \\
\hline \multicolumn{7}{|l|}{ All. Calthion palustris R. Tx. } \\
\hline Cirsium rivulare (Jacg.) All. & +-1 & - & 51 & - & II & - \\
\hline Polygonum bistorta $\mathrm{L}$. & + & 1 & 1 & 50 & $\mathrm{I}$ & $\mathrm{I}$ \\
\hline Juncus effusus L. & 2 & - & 175 & - & I & - \\
\hline Myosotis palustris (L.) L. emend. Rchb. & + & - & 2 & - & $\mathrm{I}$ & - \\
\hline \multicolumn{7}{|l|}{ O. Arrhenatheretalia Pawl. } \\
\hline Taraxacum officinale F. H. Wigg. & + & +-1 & 2 & 3 & II & II \\
\hline Achillea millefolium L. s. str. & + & - & 1 & - & $\mathrm{I}$ & - \\
\hline Leucanthemun vulgare Lam. s. str. & - & + & - & 1 & - & $\mathrm{I}$ \\
\hline Lotus corniculatus $\mathrm{L}$. & - & + & - & 1 & - & $\mathrm{I}$ \\
\hline \multicolumn{7}{|l|}{ All. Arrhenatherion Br.-BI. } \\
\hline Galium mollugo L. s. str. & +-2 & +-2 & 178 & 754 & III & $\mathrm{V}$ \\
\hline Campanula patula L. s. str. & - & + & - & 3 & $\mathrm{I}$ & II \\
\hline Arrhenatheretum elatius L. & - & 1 & - & 17 & - & $\mathrm{I}$ \\
\hline \multicolumn{7}{|l|}{ All. Cynosurion R. Tx. } \\
\hline Trifolium repens $\mathrm{L}$. & + & - & 1 & - & $\mathrm{I}$ & - \\
\hline Bromus tectorum L. & - & 2 & - & 175 & - & $\mathrm{I}$ \\
\hline Viola arvensis Murray & - & + & - & 1 & - & $\mathrm{I}$ \\
\hline Cl. Phragmitetea R. Tx. et Prsg & & & & & & \\
\hline Phragmites australis Cav. & + & + & 1 & 1 & $\mathrm{I}$ & $\mathrm{I}$ \\
\hline O. Magnocaricion Koch & & & & & & \\
\hline Phalaris arundinacea $\mathrm{L}$. & 2 & +-2 & 175 & 403 & $\mathrm{I}$ & III \\
\hline Carex acutiformis Ehrh. & - & + & - & 1 & - & $\mathrm{I}$ \\
\hline Cl. Artemisietea vulgaris $\mathrm{R} . \mathrm{Tx}$. & & & & & & \\
\hline Urtica dioica $\mathrm{L}$. & +-3 & +-3 & 1828 & 2078 & $\mathrm{~V}$ & $\mathrm{~V}$ \\
\hline Anthriscus sylvestris (L.) Hoffm. & + & +-2 & 63 & 556 & III & IV \\
\hline Linaria vulgaris Mill. & + & + & 178 & 179 & II & III \\
\hline Melandrium album (Mill.) Garcke & + & + & 3 & 2 & II & $\mathrm{I}$ \\
\hline Galium aparine L. & $1-2$ & +-2 & 400 & 353 & $\mathrm{I}$ & II \\
\hline Cirsium arvense (L.) Scop. & + & + & 2 & 1 & $\mathrm{I}$ & $\mathrm{I}$ \\
\hline Myosoton aquaticum (L.) Moench & + & - & 4 & - & $\mathrm{I}$ & - \\
\hline Carduus crispus L. & - & + & - & 3 & - & $\mathrm{I}$ \\
\hline Cl. Nardo-Callunetea Prsg. & & & & & & \\
\hline Potentilla erecta (L.) Raeusch. & + & + & 1 & 1 & $\mathrm{I}$ & $\mathrm{I}$ \\
\hline Accompanying species: & & & & & & \\
\hline Veronica chamaedrys L. s. str. & +-2 & +-1 & 356 & 58 & IV & $\mathrm{V}$ \\
\hline Cardaminopsis arenosa (L.) Hayek & +-2 & +-2 & 356 & 179 & IV & $\mathrm{V}$ \\
\hline Polemonium caeruleae L. & + & 1 & 1 & 50 & $\mathrm{I}$ & $\mathrm{I}$ \\
\hline Stellaria graminea L. & + & - & 1 & - & $\mathrm{I}$ & - \\
\hline Capsella bursa-pastoris (L.) Medik. & - & + & - & 1 & - & $\mathrm{I}$ \\
\hline
\end{tabular}

Capsella bursa-pastoris (L.) Medik.

Explanations: range of cover, cover index, constancy using the Braun-Blanquet method.

Source: own study. 
Table 2. Species richness $\mathrm{N}$ and the floristic diversity index $H^{\prime}$

\begin{tabular}{|c|c|c|c|c|}
\hline \multirow{2}{*}{ Value } & \multicolumn{2}{|c|}{$\mathrm{N}$} & \multicolumn{2}{c|}{$H^{\prime}$} \\
\cline { 2 - 5 } & 2001 & 2013 & 2001 & 2013 \\
\hline Minimum & 8 & 12 & 1.55 & 3.07 \\
\hline Maximum & 19 & 21 & 4.46 & 4.01 \\
\hline Mean & 12.2 & 16.2 & 2.8 & 3.6 \\
\hline Standard deviation & 3.74 & 2.53 & 0.86 & 0.31 \\
\hline Coefficient of variation & 30.6 & 15.6 & 30.9 & 8.6 \\
\hline Coefficient of variation & \multicolumn{3}{|c|}{25.5} & \multicolumn{3}{c|}{23.0} \\
\hline
\end{tabular}

Source: own study.

In the sward of the analysed grassland patches, the dominant species (Poa pratensis and Festuca rubra) were accompanied by a lower number of the order Arrhenatheretalia species (4 species in 2001 and 8 species in 2013; in total 10 species) than representatives of the order Molinietalia (9 species in 2001 and 10 species in 2013; total 15 species). There were also species of the Artemisietea vulgaris class (8 species). Among the accompanying species, of note is the constant presence of Veronica chamaedrys and Cardaminopsis arenosa. The sward of the Poa pratensisFestuca rubra community was characterized by a clear dominance of differential species. However, there was a substantial increase in the cover index of other species, e.g. Holcus lanatus, Deschampsia caespitosa, and Anthriscus sylvestris. The diversity of the species composition of the analysed community results from changes in habitat humidity and bad management. The patches were characterized by a high proportion of Urtica dioica (high constancy and cover index).

In the meadows located on drained organic soils in 2001 we found relevés of a very low floristic diversity $\left(H^{\prime}<2.5\right)$. Due to a tendency of increasing nonproductive functions of grasslands, it is very important to assess their aesthetic and environmental value to ensure they are suitably cared for.

\section{DISCUSSION}

The studied grassland in the Ochoża River was classified as class Molinio-Arrhenatheretea, communities Poa pratensis-Festuca rubra. Due to the lack of characteristic species suggested by MATUSZKIEWICZ [2007], the community cannot be regarded as separate. Poa pratensis and Festuca rubra are characterized by a wide ecological scale and are present in many alliances of the Molinio-Arrhenatheretea class.

In most of the analyzed patches an increase in the number of species was seen, with a mean from 12 to 16. Also, floristic diversity $H^{\prime}$ values increased from 2.8 to 3.6. Patches which saw the emergence of species of wet meadow in the Calthion palustris alliance deserve attention. Research conducted by STAMIROWSKA-KRZACZEK [2015] indicates the presence of the Poa pratensis-Festuca rubra community with a high abundance of the species. In the Wieprz River valley the presence of 10-40 species per relevé in the Poa pratensis-Festuca rubra community is revealed.
WOLAŃSKI and TRĄBA [2009] noted as many as 50 vascular plant species in patches of this community. The floristic surveys of communities revealed the occurrence of 39 vascular plant species among which the most numerous were dicotyledons, mainly herbs and weeds. All studied phytocoenoses presented in this paper belonged to the Poa pratensis-Festuca rubra community. This community is a phytocoenosis whose species composition and change in dynamics depend on the intensity of use. This is confirmed by the research conducted by WARDA and STAMIROWSKA-KRZACZEK [2010], which demonstrates that the condition of meadow ecosystems reflects not only the habitat conditions but also a change in pastoral agricultural practices. URBAN and GRZYWNA [2003] show that Urtica dioica is abundant in the Poa pratensis-Festuca rubra community on organic, strongly dry soil with a high content of nitrogen released in the process mineralization. The community occurs mesotrophic habitats of drained, extensively managed river valleys with peat-muck soils [GRZYWNA, URBAN 2008].

The lack or considerable restriction in use of valuable grass communities of the Arrhenatheretalia order causes a systematic increase in the share of dicotyledons. The range of cover of these species in the sward depends on the extent of degradation of organic soil and risosphere [WARDA et al. 2013], leading to the disappearance of valuable mown meadow communities. Typically, the meadow of this community was mown, although the land use of some small patches was discontinued. Patches of these communities occurred within the Poa pratensis-Anthriscus sylvestris communities as well as communities with Holcus lanatus and Deschampsia caespitosa. The number of species of the Magnocaricion alliance (Phalaris arundinacea, Carex acutiformis) increases in wet habitats [GRZYWNA, URBAN 2008], a fact also confirmed in the Ochoża River valley.

The lack of or intensification of use and changes in the hydrological regime result in unfavourable changes in the sward of these communities manifested in the formation of unstable transitional forms and their disappearance [QUETIER et al. 2007]. They are very interesting for their species richness. However, lack of or less intensive use of grasslands in the vicinity of neglected drainage ditches leads to the disappearance of some communities or to a reduction in their floristic diversity. The use of traditional forms of grassland management in protected areas makes it possible to preserve the semi-natural vegetation occurring there. According to WARDA et al. [2013], grassland communities which are diverse and rich in species affect landscape variety and thus its attractiveness for tourists.

\section{CONCLUSIONS}

1. In 2001, 39 species of plants were recorded in all relevés, compared to 41 species recorded in 2013. 
Over 12 years, 11 species disappeared, but 13 new ones emerged.

2. For the time being the average species richness increased from 12 to 16 per relevé. The biodiversity index $H^{\prime}$ increased from 2.8 to 3.6.

3. The cover of Poa pratensis dropped markedly (cover range decreased from 4 to 3), whereas that of Deschampsia caespitosa increased (cover range increased from 1 to 3 ).

\section{Acknowledgement}

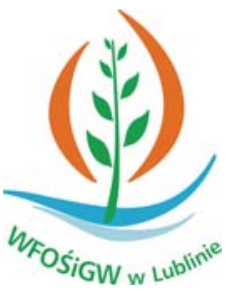

Dofinansowano ze środków

Wojewódzkiego Funduszu

Ochrony Środowiska

i Gospodarki Wodnej w Lublinie

Cofinanced by Voivodeship Fund

for Environmental Protection

and Water Management in Lublin

\section{REFERENCES}

Foster B.L., Tilman D. 2003. Seed limitation and the regulation of community structure in oak savanna grassland. Journal of Ecology. No. 91 p. 999-1007.

FukAmi T., Bezemer T.M., Mortimer S.R., VAN DER PUTTEN W.H. 2005. Species divergence and trait convergence in experimental plant community assembly. Ecology Letters. No. 8 p. 1283-1290.

GRZYWNA A., URBAN D. 2008. Zastosowanie metody fitoindykacji do identyfikacji uwilgotnienia użytków zielonych w dolinie Ochoży [Application of photo-indication method for identification of meadow habitats humidity in Ochoża valley]. Annales UMCS. Sect. E. No. 63(2) p. 90-97.

Hoelzle T.B., Jonas J.L., Paschke M.W. 2012. Twentyfive years of sagebrush steppe plant community development following seed addition. Journal of Applied Ecology. No. 49 p. 911-918.

LePs J., MichaleK J., Rauch O., Uhlik P. 2000. Early succession on plots with the upper soil horizon removed. Journal of Vegetation Science. No. 11 p. 259-264.

MatuszKiEWICZ W. 2007. Przewodnik do oznaczania zbiorowisk roślinnych Polski [Guide for the determination of plant communities in Poland]. Warszawa. PWN. ISBN 9788301167073 pp. 540.

Mirek Z., Piękoś-Mirkowa H., Zając A., Zając M. 2002. Flowering plants and pteridophytes of Poland: A checklist. Kraków. PAN. ISBN 83-85444-83-1 pp. 442.
Quetier F., Thebault A., Lavorel S. 2007. Plant traits in a state and transition framework as markers of ecosystem response to land-use change. Ecological Monographs. No. 77 p. 33-52.

STAMIROWSKA-KRZACZEK E. 2015. Występowanie zbiorowiska Poa pratensis-Festuca rubra w warunkach zaniedbań w użytkowaniu łąk [The occurrence of Poa pratensis-Festuca rubra community in terms of negligence in the use of meadows]. Annales UMCS. Sect. E. No. 70(1) p. 61-72.

URBAN D., GRZYwNA A. 2003. Zbiorowiska łakkowe z klasy Molinio-Arrhenatheretea $\mathrm{w}$ dolinie Ochoży [Meadow plant communities from the Molinio-Arrhenatheretea in the Ochoża valley]. Annales UMCS. Sect. E. No. 58 p. $155-166$.

VAN DER PutTen W.H., Mortimer S.R., HedLund K., VAN DiJK C., BROWN V.K., LEPS J. 2000. Plant species diversity as a driver of early succession in abandoned fields: a multi-site approach. Oecologia. No. 124 p. 91-99.

Wallington T.J., HobBs R.J., Moore S.A. 2005. Implications of current ecological thinking for biodiversity conservation: A review of the salient issues. Ecology and Society. No. 10 (1) p. 1-16.

WARDA M., StAmiRowSKA-KRZACZEK E. 2010. Ocena wartości runi, wilgotności i wartości troficznej siedlisk wybranych zbiorowisk trawiastych $\mathrm{z}$ klasy Molinio-Arrhenatheretea w Nadwieprzańskim Parku Krajobrazowym [Evaluation of sward value, moisture and trophism value of habitats of chosen grass communities from Molinio-Arrhenatheretea class in the Nadwieprzanski Landscape Park]. Łąkarstwo Polskie. No. 13 p. 183-195.

Warda M., Stamirowska-Krzaczek E., Kulik M. 2013. Floristic diversity of selected plant communities on extensive and abandoned grasslands in the Nadwieprzański Landscape Park. Journal of Water and Land Development. No. 19 p. 77-82.

WOLAŃSKi P., TRĄBA Cz. 2009. Walory estetyczne i rekreacyjne łąk i pastwisk położonych na Pogórzu Dynowskim [The aesthetic and recreational qualities of meadows and pastures located in the Dynowskie Foothills]. Nauka Przyroda Technologia. Vol. 3(1) p. 1-8.

Woodcock B.A., Bullock J.M., Mortimer S.R., PYwell R.F. 2012. Limiting factors in the restoration of UK grassland beetle assemblages. Biological Conservation. No. 146 p. 136-143.

Zhang J., Zhao H., Zhang T., Zhao X., Drake S. 2005. Community succession along a chronosequence of vegetation restoration on sand dunes in Horqin Sandy Land. Journal of Arid Environments. Vol. 62 p. 555566.

\section{Danuta URBAN, Antoni GRZYWNA}

\section{Zmiany w składzie gatunkowym zbiorowiska Poa pratensis-Festuca rubra na odwodnionym torfowisku}

\section{STRESZCZENIE}

W artykule przedstawiono wyniki badań fitosocjologicznych na obiekcie Ochoża prowadzonych w 2001 i 2013 r. Z analizy danych wynika, że gatunkami występującymi na wszystkich badanych stanowiskach były głównie Poa pratensis i Festuca rubra oraz Urtica dioica. W 2013 r. na wszystkich badanych stanowiskach, oprócz gatunków omówionych wyżej, występowały także Rumex acetosa, Galium mollugo, Veronica chamae- 
drys i Cardaminopsis arenosa. Na podstawie analizy wyników badań stwierdzono, że w przypadku 15 gatunków klasa stałości w 2013 r. w porównaniu ze stanem z 2001 r. zwiększyła się, a w przypadku pozostałych się nie zmieniła. Odnotowano także zmiany współczynnika pokrycia. Uległ on znacznemu zmniejszeniu w przypadku 8 gatunków, a zwiększył się w przypadku 12 gatunków. Na szczególną uwagę zasługuje duże zwiększenie wartości współczynnika pokrycia Holcus lanatus, Deschampsia caespitosa, Galium mollugo, Anthriscus sylvestris oraz Polemonium caeruleae (w Polsce gatunek objęty ochroną prawną). W 2001 r. we wszystkich stanowiskach odnotowano 39 gatunków roślin, zaś w 2013 r. odnotowano 41 gatunków. Przez 12 lat zanikło 11 gatunków, ale pojawiło się 13 nowych. Przez 12 lat średnia liczba gatunków $N$ zwiększyła się z 12 do 16 . Zwiększył się także wskaźnik bioróżnorodności $H^{\prime}$ z 2,8 do 3,6.

Słowa kluczowe: bioróżnorodność, bogactwo gatunkowe, dolina rzeczna, zdjęcie fitosocjologiczne 